NBER WORKING PAPER SERIES

\title{
FINANCIAL FRAUD AMONG OLDER AMERICANS: EVIDENCE AND IMPLICATIONS
}

\author{
Marguerite DeLiema \\ Martha Deevy \\ Annamaria Lusardi \\ Olivia S. Mitchell \\ Working Paper 24803 \\ http://www.nber.org/papers/w24803 \\ NATIONAL BUREAU OF ECONOMIC RESEARCH \\ 1050 Massachusetts Avenue \\ Cambridge, MA 02138 \\ July 2018
}

The authors thank Yong Yu for expert programming on this project, and Paul Yakoboski for helpful comments. This work was supported by a grant from the U.S. Social Security Administration (SSA) funded as part of the Retirement Research Consortium through the University of Michigan Retirement Research Center, Award RRC08098401. The authors also received research support from the TIAA Institute and The Pension Research Council/Boettner Center at The Wharton School of the University of Pennsylvania. This research is also part of the NBER Program on Aging. Opinions and conclusions are solely those of the authors and do not represent the opinions or policy of the TIAA Institute or TIAA, SSA, or any agency of the Federal Government. Neither the United States Government nor any agency thereof nor any of their employees makes any warranty, express or implied, or assumes any legal liability or responsibility for the accuracy, completeness, or usefulness of the contents of this report. Any reference herein to any specific commercial product, process, or service by trade name, trademark, manufacturer, or otherwise does not constitute or imply endorsement, recommendation or favoring by the United States Government or any agency thereof. The views expressed herein are those of the authors and do not necessarily reflect the views of the National Bureau of Economic Research.

At least one co-author has disclosed a financial relationship of potential relevance for this research. Further information is available online at http://www.nber.org/papers/w24803.ack

NBER working papers are circulated for discussion and comment purposes. They have not been peer-reviewed or been subject to the review by the NBER Board of Directors that accompanies official NBER publications.

(C) 2018 by Marguerite DeLiema, Martha Deevy, Annamaria Lusardi, and Olivia S. Mitchell. All rights reserved. Short sections of text, not to exceed two paragraphs, may be quoted without explicit permission provided that full credit, including $\odot$ notice, is given to the source. 
Financial Fraud among Older Americans: Evidence and Implications

Marguerite DeLiema, Martha Deevy, Annamaria Lusardi, and Olivia S. Mitchell

NBER Working Paper No. 24803

July 2018

JEL No. D14,D18

\begin{abstract}
The consequences of poor financial capability at older ages are serious and include making mistakes with credit, spending retirement assets too quickly, and being defrauded by financial predators. Because older persons are at or past the peak of their wealth accumulation, they are often the targets of fraud. Our project analyzes a module we developed and fielded in the 2016 Health and Retirement Study (HRS). Using this dataset, we evaluate the incidence and risk factors for investment fraud, prize/lottery scams, and account misuse, using regression analysis. Relatively few HRS respondents mentioned any single form of fraud over the prior five years, but nearly $5 \%$ reported at least one form of investment fraud, $4 \%$ recounted prize/lottery fraud, and $30 \%$ indicated that others had used/attempted to use their accounts without permission. There were few risk factors consistently associated with such victimization in the older population. Fraud is a complex phenomenon and no single factor uniquely predicts victimization. The incidence of fraud could be reduced by educating consumers about various types of fraud and by increasing awareness among financial service professionals.

Marguerite DeLiema

Stanford Center on Longevity

579 Serra Mall

Stanford, CA 94305

deliema@stanford.edu

Martha Deevy

Stanford Center on Longevity

579 Serra Mall

Stanford, CA 94305

mdeevy@stanford.edu

Annamaria Lusardi

The George Washington University

School of Business

2201 G Street, NW

Duques Hall, Suite 450E

Washington, DC 20052

and NBER

alusardi@gwu.edu

Olivia S. Mitchell

University of Pennsylvania

The Wharton School

3620 Locust Walk, St 3000 SH-DH

Philadelphia, PA 19104-6302

and NBER

mitchelo@wharton.upenn.edu
\end{abstract}




\title{
Financial Fraud among Older Americans: Evidence and Implications
}

\author{
Marguerite DeLiema, Martha Deevy, Annamaria Lusardi, and Olivia S. Mitchell
}

The greying of the U.S. population is ushering in a growing need for assistance with key financial decisions. The consequences of poor financial literacy and capability at older ages are serious (see Agarwal et al., 2009; Karp \& Wilson, 2011; Lusardi, Mitchell \& Curto, 2014), particularly when people make mistakes with credit, draw down retirement assets too quickly, and are deceived out of their savings by financial predators. Highlighting older persons’ vulnerability to fraud, a FINRA Investor Education Foundation study (2013) found that more than $80 \%$ of adults of all ages had been solicited for potentially fraudulent offers, but older Americans were particularly likely to be targeted and lose money.

Using an experimental module in the 2016 Health and Retirement Study (HRS) that we designed, we evaluate older Americans' exposure to three subtypes of financial fraud and explore how financial literacy and self-rated financial knowledge relate to victimization, controlling for cognitive performance, depression, and physical and functional health, measured prospectively.

\section{Background}

Despite increasing media attention regarding the threat of consumer fraud targeting older people, researchers have only made limited progress in identifying at-risk groups for tailored prevention and intervention programs (Deevy, Lucich \& Beals, 2012). One challenge has been inconsistent findings regarding how age, socioeconomic status, financial sophistication, and other

factors relate to fraud susceptibility. For example, AARP (2011) found that lottery fraud and 
investment fraud victims differed across nearly all demographic and socioeconomic characteristics including financial literacy scores.

Given the variation in victim profiles, researchers should distinguish fraud types, yet the HRS “Leave Behind” questionnaires asked respondents only one broad question without defining fraud or specifying any particular scam type. The question asked was: "Have you been a victim of fraud five years?” (yes/no). Between 5-6\% indicated they were victims (DeLiema et al., 2017), lower than in a national telephone survey conducted by the Federal Trade Commission (FTC) that covered multiple fraud subtypes and found prior-year prevalence rates between $6.5 \%-14.3 \%$ (Anderson, 2013). ${ }^{1}$ A limitation of that survey, as true in most fraud victimization studies, is that those data were cross-sectional. By contrast, the HRS data are collected every two years, allowing researchers to analyze the health, social, and financial antecedents of fraud.

To address limitations of prior studies, we consulted with fraud experts to design a module in the 2016 HRS. This permitted us to evaluate the incidence and determinants of three different fraud types relevant for the older population: investment fraud, prize/lottery fraud, and account misuse. Moreover, we can examine the associations between risk of victimization and a large set of factors.

\section{Methods}

Our HRS module (see Online Appendix A) was administered to 1,268 randomly selected survey participants age 50 and older in the 2016 survey wave. ${ }^{2}$ In prior research, analysts framing questions about fraud in a criminal context found that it significantly reduced disclosure among

\footnotetext{
${ }^{1}$ Past-year fraud prevalence was $14.3 \%$ among adults ages 45-54, 9.1\% among adults ages 55-64, 7.3\% among adults ages $65-74$, and $6.5 \%$ among adults ages 75 and older.

${ }^{2}$ For detailed information on the HRS, visit http://hrsonline.isr.umich.edu/.
} 
women and older people (Beals et al., 2015). Therefore, unlike the HRS Leave Behind surveys that asked respondents to identify themselves as fraud victims, our module queried about specific types of financial decisions and experiences often equivalent to fraud (see also FINRA, 2013). For example, investment fraud was measured using four items capturing risky investments and solicitation methods—e.g., penny stocks, "free lunch" seminars, unknown callers—and one general "catch-all” item that asked whether the respondent (or the respondent's spouse/partner) put money into any type of fraudulent investment in the past five years. Those who replied 'yes' to any of these five items were classified as investment fraud victims. Respondents who paid money to someone in order to obtain supposed lottery winnings or a prize (e.g., money, free vacation, product or service) were classified as prize/lottery fraud victims. Those who reported that someone used or attempted to use their existing accounts (e.g., credit or debit cards, checking, savings, telephone, online, or insurance accounts) were classified as victims or attempted victims of account misuse.

The HRS module also included the "Big Three" financial literacy questions from Lusardi and Mitchell (2014) and respondents were scored based on their correct answers (range $=0-3$ ). Self-rated financial knowledge was reported on a scale of 1-7, with 7 being the most confident.

We use Probit multivariate regression analysis to examine the potential risk factors for each fraud subtype. The marginal effects reported in the table can be interpreted as the percentage change in the outcome probability for a one-unit increase in the independent variable. Controls include age, sex, race/ethnicity, education, marital status, number of children, cognition score (TICS) ${ }^{3}$, number of limitations in activities of daily living (ADL), depression symptoms (CES-D

\footnotetext{
${ }^{3}$ See Clair et al. (2011). The cognitive functioning measure includes performance on immediate and delayed word recall, serial 7s test, counting backwards, naming tasks (e.g., date-naming), and vocabulary questions. The mental status index sums scores from counting, naming, and vocabulary tasks. The total cognition score sums the total recall and mental status indices. For further detail, see Fisher et al. (2017).
} 
score), self-reported health status, and net housing ${ }^{4}$ as well as non-housing net wealth ${ }^{5}(\$ 2014)$.

These data were collected as part of the 2010 core HRS survey wave (pre-fraud). (Additional robustness analyses are provided in Online Appendix B.)

\section{Results}

\section{Descriptive Statistics}

Table 1 reports descriptive statistics: on average, respondents scored 2.2 correct of 3 financial literacy questions. Mean self-rated financial knowledge was 5.0 of 7, indicating a fair amount of self-confidence. Respondents’ average age was 68.2; 44.5\% were male; 59.5\% were married or partnered; 82.2\% were White; and 8.4\% Hispanic. Average educational attainment was 13.3 years and the average number of children was 2.8. Mean non-housing net wealth was $\$ 171,000$ (\$2014), and total net housing wealth $\$ 154,000$ (\$2014). Seventy-three percent reported their physical health was good to excellent; few reported symptoms of depression (average was 1.2 out of 8 ); and the average cognition score was 23.7 of a possible 27 points.

Table 2 presents fraud prevalence. Though each specific form of investment fraud is rare, $4.9 \%$ of the respondents indicated that they had made one fraudulent investment in the past five years: $2.7 \%$ had invested after a "free meal” seminar, $0.9 \%$ had invested in response to a phone or email solicitation from an unknown person, 1.0\% invested in a penny stock or oil-and-gas deal, and $1.0 \%$ purchased a fraudulent investment (“catch all” item). Only $0.4 \%$ reported having bought what turned out to be a fraudulent investment based on a relative’s recommendation. ${ }^{6}$

\footnotetext{
${ }^{4}$ Total net housing wealth included the net value of the household's primary (and if relevant, secondary) residence.

${ }^{5}$ This included the value of stocks, mutual funds, investment trusts, checking, savings, money market accounts, CDs, government savings bonds, and T-bills, bonds, and bond funds, and all other savings, minus all debt.

${ }^{6}$ Interestingly, few of the individual fraud indicators were highly correlated, suggesting that most respondents only experienced one of the measured fraud subtypes in the past five years.
} 
Four percent of respondents reported prize/lottery fraud victimization in the past five years. As many as $29.5 \%$ said that others had used or attempted to use one or more of the respondent's accounts without permission. We acknowledge that this question did not differentiate respondents who were victims of account misuse from those who were targeted, but it is striking that $34.8 \%$ of the overall sample reported having been subjected to some form of actual or attempted fraud in the past five years. Accordingly, we argue that the extent of financial fraud experienced by the over50 population is non-negligible.

\section{Factors Associated with Fraud Victimization}

Table 3 shows that other than depression, relatively few variables were consistently statistically significant across fraud subtypes. Financial literacy is negatively associated with the probability of investing with an unknown person, but positively related to investing based on a free meal seminar. Those rating themselves as very financially knowledgeable were significantly more likely to indicate that an account of theirs had been used (or attempted to have been used) without permission.

Greater levels of depression were associated with prize/lottery fraud, account misuse, and investment fraud. There was no systematic association between being victimized and age, wealth, health or depression, sex, marital status, or education across subtypes. Hispanics were significantly less likely to have reported being scammed by prize/lottery fraud, account misuse, and some forms of investment fraud. Indeed, this analysis underscores that few readily-identifiable risk factors are predictive of major subtypes of fraud.

\section{Discussion}


There has been much recent debate about whether older Americans make well-informed financial decisions and whether they face higher fraud risk. Prior to our experimental module, there had been no fraud victimization studies using the HRS's rigorous sampling approach to determine the prevalence and determinants of multiple forms of fraud. By linking the new information from our module to the core HRS variables, we develop a more comprehensive profile of older adults who are victimized.

Our results indicate that relatively few HRS respondents experienced any specific type of investment fraud in the past five years, but 5\% did report at least one form of investment fraud and 4\% paid money because they believed they needed to pay in order to claim a prize or lottery. More alarming is that nearly one-third of respondents reported that someone had used or attempted to use their financial accounts in the past five years. This figure is considerably higher than the fiveyear prevalence of conventionally-measured fraud, indicating that actual and attempted financial exploitation by family and friends or identity theft by strangers is a significant concern for older Americans. This question did not differentiate between successful and attempted account misuse or specify the victim's relationship to the perpetrator (stranger versus friend/relative). More research is needed to determine how often money is lost in such incidents, who perpetrated the crime, and whether losses were recovered or reimbursed by financial institutions.

Overall prevalence was higher than in the HRS Leave Behind questionnaires that only included a single fraud item without offering specific examples of fraudulent behavior (DeLiema et al., 2017). Those lower rates resulted despite the fact that respondents could have reported on a broader range of fraud experiences not included in the new module. This suggests that informing people about how one defines fraud is important for obtaining a more precise estimate of victimization. 
Other than depression, few readily-identifiable factors were associated with victimization in the older population. Neither financial literacy nor self-reported financial knowledge were consistently and significantly associated with any key outcome, nor were net housing or nonhousing wealth, race/ethnicity, education, marital status, or age. We find that those reporting themselves as financially knowledgeable were also more likely to indicate account misuse; this could imply that the more self-confident were better at monitoring their accounts and thus more likely to detect suspicious activity, rather than experiencing more account misuse than their lessconfident peers. If anything, our research illustrates that more financially literate and educated adults are not necessarily immune to financial fraud, and that predicting financial victimization is not a simple matter.

Lack of consistency in predictor variables across fraud subtypes could suggest that unmeasured situational factors play a larger role, such as whether the respondent was alone when solicited or in a state of high emotional arousal boosting susceptibility (Kircanski et al., 2018). Another determinant might be lack of knowledge of specific scams or the tactics scammers use to deceive targets. If context and prior knowledge are more prognostic of victimization than sociodemographic factors and financial literacy, consumer education messages should focus on strategies for resisting persuasion and tools for safeguarding financial accounts against malicious actors and impulsive decision-making.

AARP (2011) has previously argued that investment fraud victims were likely to be male, well-educated, and relatively well paid. Nevertheless, respondents in that study were recruited from a sample of known fraud victims identified by law enforcement. By contrast, our HRS module was administered to a randomly selected and nationally representative subset of older Americans. Accordingly, our findings are more reflective of the older population at large, rather 
than a subset of victims. As a result, we can be relatively confident that our results are likely to be generalizable across the older population.

\section{Conclusion}

Older adults may require assistance to manage their finances and avoid fraud, so financial advisors and institutions could enhance protections and offer monitoring tools that reduce opportunities for exploitation. Preventing fraud is a shared responsibility between consumers and banks, insurance, and credit card companies holding and managing their accounts. Future studies will need to explore the effects of financial literacy and confidence on risk of other types of scams. When additional waves of the HRS become available, researchers will be able to link fraud victimization to subsequent changes in wealth and retirement well-being. 


\section{References}

AARP. (2011). AARP Foundation National Fraud Victim Study. Report by K. Pak and D. Shadel. Washington, D.C.

Agarwal, S., Driscoll, J. C., Gabaix, X., \& Laibson, D. (2009). The age of reason: Financial decisions over the life cycle and implications for regulation. Brookings Papers on Economic Activity, 2, 51-117.

Anderson, K. B. (2013). Consumer fraud in the United States, 2011: The third FTC survey. The Federal Trade Commission. Washington, DC.

Beals, M. E., Carr, D. C., Mottola, G. R., Deevy, M. J., \& Carstensen, L. L. (2015). How does survey context impact self-reported fraud victimization? The Gerontologist, 57(2), 329340.

Clair, P. S., Bugliari, D., Campbell, N., Chien, S., Hayden, O., Hurd, M., \& Pantoja, P. (2011). RAND HRS data documentation-Version L. Santa Monica: RAND Corporation.

Deevy, M., Lucich, S., \& Beals, M. (2012). Scams, schemes, \& swindles: A review of consumer fraud research. Financial Fraud Research Center: Stanford Center on Longevity. Stanford, CA.

DeLiema, M., Deevy, M., Lusardi, A., \& Mitchell, O. S. (2017). Exploring the risks and consequences of elder fraud victimization: Evidence from the Health and Retirement Study. Report for the TIAA Institute.

FINRA Investor Education Foundation. (2013). Financial fraud and fraud susceptibility in the United States. Research Report from a 2012 National Survey. Applied Research and Consulting: New York, NY.

Fisher, G. G., Hassan, H., Faul, J. D., Rodgers, W. L., \& Weir, D. R. (2017). HRS Imputation of 
Cognitive Functioning Measures: 1992 - 2014 Data Description (Final Release Version). http:/hrsonline.isr.umich.edu/modules/meta/xyear/cogimp/desc/COGIMPdd.pdf

Karp, N., \& Wilson, R. (2011). Protecting older investors: The challenge of diminished capacity. AARP Public Policy Institute Working Paper.

Kircanski, K., Notthoff, N., DeLiema, M., Samanez-Larkin, G. R., Shadel, D., Mottola, G., \& Gotlib, I. H. (2018). Emotional arousal may increase susceptibility to fraud in older and younger adults. Psychology and Aging, 33(2), 325-337.

Lusardi, A., \& Mitchell, O. S. (2014). The economic importance of financial literacy: Theory and evidence. Journal of Economic Literature, 52(1), 5-44.

Lusardi, A., Mitchell, O. S. \& Curto V. (2014). Financial literacy and financial sophistication in the older population. Journal of Pension Economics and Finance, 13(4), 347-366. 
Table 1. Sample Characteristics $(\mathrm{N}=1,268)$

Mean/Frequency Sd.Dev.

\begin{tabular}{lcc}
\hline Age & 68.22 & 8.94 \\
Male & $44.45 \%$ & 0.50 \\
White & $82.23 \%$ & 0.38 \\
Hispanic & $8.36 \%$ & 0.28 \\
Education (yrs.) & 13.32 & 2.96 \\
Married & $59.45 \%$ & 0.49 \\
Number of children & 2.83 & 1.93 \\
Cognition score (1-27) & 23.67 & 4.21 \\
Depression symptoms (0-8) & 1.22 & 1.85 \\
Self-rated health good-excellent (vs. fair-poor) & $73.32 \%$ & 0.44 \\
Non-housing wealth (/100k, 2014\$) & 1.71 & 6.36 \\
Housing wealth (/100k, 2014\$) & 1.54 & 2.27 \\
Financial literacy score (0-3) & 2.15 & 0.91 \\
Self-rated financial knowledge (1-7) & 4.97 & 1.51 \\
\hline
\end{tabular}


Table 2. Past 5-year prevalence of fraud by subtype $(\mathrm{N}=1,268)$

\begin{tabular}{lccc} 
Variable & $\mathbf{N}$ & Frequency & Sd.Dev. \\
\hline Invested based on a free meal seminar & 1,256 & $2.66 \%$ & 0.16 \\
Invested based on a phone call from unknown person & 1,260 & $0.89 \%$ & 0.09 \\
Invested in penny stocks and/or oil-gas exploration & 1,253 & $1.04 \%$ & 0.10 \\
Put money in fraudulent investment & 1,254 & $1.00 \%$ & 0.10 \\
Fraud investment recommended by a relative & 1,256 & $0.35 \%$ & 0.06 \\
Investment fraud total: Any fraudulent investment & 1,244 & $4.91 \%$ & 0.22 \\
Paid to receive a prize/lottery/award & 1,257 & $4.33 \%$ & 0.20 \\
Account used/attempted to be used without permission & 1,256 & $29.53 \%$ & 0.46 \\
Total: Any successful/attempted fraud in past 5 years & 1,260 & $34.84 \%$ & 0.48 \\
\hline
\end{tabular}


Table 3. Weighted Probit models predicting fraud victimization by subtype

\begin{tabular}{|c|c|c|c|c|c|c|c|c|c|c|c|c|c|}
\hline \multirow[b]{2}{*}{ Age } & \multicolumn{2}{|c|}{$\begin{array}{l}\text { Invested: free } \\
\text { meal }\end{array}$} & \multicolumn{2}{|c|}{$\begin{array}{l}\text { Invested: } \\
\text { phone call/ } \\
\text { unknown } \\
\text { person } \\
\end{array}$} & $\begin{array}{c}\text { Invested: } \\
\text { penny stocks/ } \\
\text { oil-gas } \\
\text { exploration } \\
\end{array}$ & \multirow{2}{*}{$\begin{array}{c}\begin{array}{c}\text { Invested: } \\
\text { relative's } \\
\text { recommendati } \\
\text { on }\end{array} \\
0.0000 \\
(0.0000)\end{array}$} & $\begin{array}{l}\text { Investment: Put } \\
\text { \$ into fraudulent } \\
\text { investment }\end{array}$ & \multicolumn{2}{|c|}{$\begin{array}{c}\text { Any } \\
\text { investment } \\
\text { fraud past 5- } \\
\text { yrs. }\end{array}$} & \multicolumn{2}{|c|}{$\begin{array}{l}\text { Paid to } \\
\text { receive prize/ } \\
\text { lottery }\end{array}$} & \multicolumn{2}{|c|}{$\begin{array}{c}\text { Attempted/ } \\
\text { successful } \\
\text { account } \\
\text { misuse } \\
\end{array}$} \\
\hline & $\begin{array}{r}0.0003 \\
(0.0002)\end{array}$ & $* *$ & $\begin{array}{r}0.0000 \\
(0.0001)\end{array}$ & & $\begin{array}{r}0.0000 \\
(0.0000)\end{array}$ & & $\begin{array}{r}0.0000 \\
(0.0000)\end{array}$ & $\begin{array}{r}0.0009 \\
(0.0006)\end{array}$ & & $\begin{array}{r}0.000 \\
(0.001)\end{array}$ & & $\begin{array}{r}-0.005 \\
(0.002)\end{array}$ & $* *$ \\
\hline Male & $\begin{array}{r}0.0014 \\
(0.0037)\end{array}$ & & $\begin{array}{r}-0.0005 \\
(0.0013)\end{array}$ & & $\begin{array}{r}-0.0003 \\
(0.0002)\end{array}$ & $\begin{array}{r}0.0004 \\
(0.0004)\end{array}$ & $\begin{array}{r}0.0000 \\
(0.0002)\end{array}$ & $\begin{array}{r}0.0131 \\
(0.0127)\end{array}$ & & $\begin{array}{r}0.009 \\
(0.011)\end{array}$ & & $\begin{array}{r}0.057 \\
(0.036)\end{array}$ & \\
\hline White & $\begin{array}{r}-0.0067 \\
(0.0052)\end{array}$ & & $\begin{array}{r}-0.0019 \\
(0.0017)\end{array}$ & & $\begin{array}{r}0.0000 \\
(0.0002)\end{array}$ & $\begin{array}{r}0.0001 \\
(0.0002)\end{array}$ & $\begin{array}{r}0.0001 \\
(0.0002)\end{array}$ & $\begin{array}{r}-0.0224 \\
(0.0145)\end{array}$ & & $\begin{array}{r}-0.024 \\
(0.020)\end{array}$ & & $\begin{array}{r}0.044 \\
(0.041)\end{array}$ & \\
\hline Hispanic & $\begin{array}{r}-0.0055 \\
(0.0026)\end{array}$ & $* *$ & $\begin{array}{r}-0.0051 \\
(0.0019)\end{array}$ & $* * *$ & $\begin{array}{r}-0.0006 \\
(0.0004)\end{array}$ & $\begin{array}{r}0.0000 \\
(0.0003)\end{array}$ & $\begin{array}{r}-0.0011 \\
(0.0007)\end{array}$ & $\begin{array}{r}-0.0307 \\
(0.0077)\end{array}$ & $* * *$ & $\begin{array}{r}-0.034 \\
(0.007)\end{array}$ & $* * *$ & $\begin{array}{r}-0.119 \\
(0.046)\end{array}$ & $* * *$ \\
\hline Education (yrs.) & $\begin{array}{r}-0.0009 \\
(0.0007)\end{array}$ & & $\begin{array}{r}0.0001 \\
(0.0002)\end{array}$ & & $\begin{array}{r}0.0001 \\
(0.0001)\end{array}$ & $\begin{array}{r}0.0000 \\
(0.0000)\end{array}$ & $\begin{array}{r}0.0001 \\
(0.0001)\end{array}$ & $\begin{array}{r}0.0027 \\
(0.0025)\end{array}$ & & $\begin{array}{r}-0.001 \\
(0.002)\end{array}$ & & $\begin{array}{r}0.025 \\
(0.007)\end{array}$ & $* * *$ \\
\hline Married & $\begin{array}{r}0.0037 \\
(0.0038)\end{array}$ & & $\begin{array}{r}0.0023 \\
(0.0015)\end{array}$ & & $\begin{array}{r}-0.0002 \\
(0.0002)\end{array}$ & $\begin{array}{r}-0.0004 \\
(0.0005)\end{array}$ & $\begin{array}{r}0.0005 \\
(0.0004)\end{array}$ & $\begin{array}{r}0.0133 \\
(0.0118)\end{array}$ & & $\begin{array}{r}0.020 \\
(0.011)\end{array}$ & $*$ & $\begin{array}{r}0.061 \\
(0.036)\end{array}$ & $*$ \\
\hline Number of children & $\begin{array}{r}0.0012 \\
(0.0006)\end{array}$ & $* *$ & $\begin{array}{r}0.0000 \\
(0.0003)\end{array}$ & & $\begin{array}{r}0.0000 \\
(0.0001)\end{array}$ & $\begin{array}{r}0.0001 \\
(0.0001)\end{array}$ & $\begin{array}{r}0.0001 \\
(0.0001)\end{array}$ & $\begin{array}{r}0.0034 \\
(0.0022)\end{array}$ & & $\begin{array}{r}0.003 \\
(0.003)\end{array}$ & & $\begin{array}{r}0.015 \\
(0.009)\end{array}$ & $*$ \\
\hline Cognition score & $\begin{array}{r}0.0015 \\
(0.0005)\end{array}$ & $* * *$ & $\begin{array}{r}-0.0001 \\
(0.0001)\end{array}$ & & $\begin{array}{r}0.0000 \\
(0.0000)\end{array}$ & $\begin{array}{r}0.0001 \\
(0.0001)\end{array}$ & $\begin{array}{r}0.0000 \\
(0.0000)\end{array}$ & $\begin{array}{r}0.0019 \\
(0.0017)\end{array}$ & & $\begin{array}{r}-0.001 \\
(0.002)\end{array}$ & & $\begin{array}{r}0.001 \\
(0.005)\end{array}$ & \\
\hline CESD score & $\begin{array}{r}0.0008 \\
(0.0007)\end{array}$ & & $\begin{array}{r}0.0001 \\
(0.0002)\end{array}$ & & $\begin{array}{r}0.0001 \\
(0.0001)\end{array}$ & $\begin{array}{r}0.0000 \\
(0.0001)\end{array}$ & $\begin{array}{r}0.0001 \\
(0.0001)\end{array}$ & $\begin{array}{r}0.0040 \\
(0.0024)\end{array}$ & $*$ & $\begin{array}{r}0.008 \\
(0.003)\end{array}$ & $* *$ & $\begin{array}{r}0.021 \\
(0.010)\end{array}$ & $* *$ \\
\hline $\begin{array}{l}\text { Self-rated health } \\
\text { good-excellent }\end{array}$ & $\begin{array}{r}0.0045 \\
(0.0035)\end{array}$ & & $\begin{array}{r}-0.0018 \\
(0.0021)\end{array}$ & & $\begin{array}{r}-0.0003 \\
(0.0005)\end{array}$ & $\begin{array}{r}-0.0003 \\
(0.0002)\end{array}$ & $\begin{array}{r}-0.0011 \\
(0.0007)\end{array}$ & $\begin{array}{r}-0.0233 \\
(0.0166)\end{array}$ & & $\begin{array}{r}0.016 \\
(0.014)\end{array}$ & & $\begin{array}{r}-0.066 \\
(0.046)\end{array}$ & \\
\hline $\begin{array}{l}\text { Non-housing wealth } \\
\text { (/100k, 2014\$) }\end{array}$ & $\begin{array}{r}0.0002 \\
(0.0002)\end{array}$ & & $\begin{array}{r}-0.0001 \\
(0.0001)\end{array}$ & & $\begin{array}{r}0.0000 \\
(0.0000)\end{array}$ & $\begin{array}{r}0.0000 \\
(0.0000)\end{array}$ & $\begin{array}{r}0.0000 \\
(0.0000)\end{array}$ & $\begin{array}{r}0.0017 \\
(0.0008)\end{array}$ & $* *$ & $\begin{array}{r}0.000 \\
(0.001)\end{array}$ & & $\begin{array}{r}-0.007 \\
(0.003)\end{array}$ & $* *$ \\
\hline $\begin{array}{l}\text { Housing wealth }(/ 100 k \text {, } \\
\text { 2014\$) }\end{array}$ & $\begin{array}{r}0.0002 \\
(0.0009)\end{array}$ & & $\begin{array}{r}0.0002 \\
(0.0002)\end{array}$ & & $\begin{array}{r}0.0000 \\
(0.0000)\end{array}$ & $\begin{array}{r}-0.0001 \\
(0.0000)\end{array}$ & $\begin{array}{r}0.0000 \\
(0.0000)\end{array}$ & $\begin{array}{r}0.0009 \\
(0.0027)\end{array}$ & & $\begin{array}{r}-0.004 \\
(0.003)\end{array}$ & & $\begin{array}{r}0.019 \\
(0.008)\end{array}$ & $* *$ \\
\hline Financial literacy & $\begin{array}{r}0.0042 \\
(0.0023)\end{array}$ & $*$ & $\begin{array}{r}-0.0010 \\
(0.0006)\end{array}$ & $*$ & $\begin{array}{r}0.0001 \\
(0.0001)\end{array}$ & $\begin{array}{r}-0.0001 \\
(0.0001)\end{array}$ & $\begin{array}{r}-0.0002 \\
(0.0002)\end{array}$ & $\begin{array}{r}0.0002 \\
(0.0065)\end{array}$ & & $\begin{array}{r}-0.005 \\
(0.007)\end{array}$ & & $\begin{array}{r}0.019 \\
(0.022)\end{array}$ & \\
\hline $\begin{array}{l}\text { Self-rated } \\
\text { financial knowledge }\end{array}$ & $\begin{array}{r}-0.0011 \\
(0.0012)\end{array}$ & & $\begin{array}{r}-0.0002 \\
(0.0003)\end{array}$ & & $\begin{array}{r}0.0001 \\
(0.0001)\end{array}$ & $\begin{array}{r}0.0000 \\
(0.0000)\end{array}$ & $\begin{array}{l}-0.0001 \\
(0.0001)\end{array}$ & $\begin{array}{r}-0.0005 \\
(0.0036)\end{array}$ & & $\begin{array}{r}0.001 \\
(0.004)\end{array}$ & & $\begin{array}{r}0.024 \\
(0.011)\end{array}$ & $* *$ \\
\hline
\end{tabular}




\begin{tabular}{|c|c|c|c|c|c|c|c|c|}
\hline $\mathbf{N}$ & 1,256 & 1,260 & 1,253 & 1,256 & 1,254 & 1,244 & 1,257 & 1,256 \\
\hline Pseudo R-sq & 0.107 & 0.112 & 0.294 & 0.205 & 0.192 & 0.088 & 0.067 & 0.078 \\
\hline
\end{tabular}

Note: ${ }^{*} \mathrm{p}<0.10, * * \mathrm{p}<0.05, * * * \mathrm{p}<0.01$. Dummies included for missing variables. Standard errors clustered at household level. 


\section{Online Appendix A. 2016 HRS Fraud and Victimization Module: Financial Mismanagement at Older Ages}

By Martha Deevy, Martha DeLiema, Annamaria Lusardi, and Olivia Mitchell

Variables in this module: V051 - V067

[SELF-INTERVIEWS ONLY]

V051_RATEKNOWLEDG

RATE OVERALL FINANCIAL KNOWLEDGE

These next questions are about finances and managing money. The first question is . . On a scale from 1 to 7, where 1 means very low and 7 means very high, how would you assess your overall financial knowledge?

Range: 1 - 7

8. DK

9. RF

V052_100D2PCT-5YR

BIG THREE NO 1: INVEST 100 DOLLARS AT 2 PCT IN 5 YEARS

Suppose you had $\$ 100$ in a savings account and the interest rate was $2 \%$ per year. After 5 years, how much do you think you would have in the account if you left the money to grow - more than \$102, exactly

$\$ 102$, or less than $\$ 102$ ?

1. More than $\$ 102$

2. Exactly $\$ 102$

3. Less than $\$ 102 \mathrm{DK}$

9. $\mathrm{RF}$

\section{V053_100D1PCTINF2}

BIG THREE NO 2: \$100 AT 1 PCT INFLATION 2 PCT 1 YEAR

Imagine that the interest rate on your savings account was $1 \%$ per year and inflation was $2 \%$ per year. After 1 year, how much would you be able to buy with the money in this account - more than today, exactly the same as today, or less than today?

1. More than today

2. Exactly the same

3. Less than today

8. DK

9. $\mathrm{RF}$

\section{V054_STOCK-MUTFND}

BIG THREE NO 3: SINGLE CO. STOCK SAFER THAN MUTUAL FUND

Is the following statement true or false: buying a single company's stock usually provides a safer return than a stock mutual fund?
1. True
2. False
8. DK
9. $\mathrm{RF}$

\section{V055_DECUMULATION DECUMULATION QUESTION}

Suppose you had $\$ 100$ in a checking account that pays no interest. If you withdrew 5 percent of what was left in the account each year, how much do you think you would have left in the account at the end of 2 years - more than $\$ 90$, exactly $\$ 90$, or less than $\$ 90$ ?

1. More than $\$ 90$ 
2. Exactly $\$ 90$

3. Less than $\$ 90$

8. DK

9. $\mathrm{RF}$

\section{V056_RUNNINGOUT}

WORRIED ABOUT RUNNING OUT OF MONEY

Are you worried about running out of money during your retirement?

$\begin{array}{ll}\text { 1. } & \text { Yes } \\ \text { 5. } & \text { No } \\ \text { 8. } & \text { DK } \\ \text { 9. } & \text { RF }\end{array}$

V057_GUARANTEED

FINANCIAL FRAUD AWARENESS - GUARANTEED INVESTMENT

Now I'd like to read some statements describing some potential investment opportunities. After hearing about each one, please tell me how interested you would be in that investment. Use a scale of 1 to 10 , where 1 means you would not be at all interested, and 10 means you would be extremely interested.

Here is the first description:

There is no way to lose on this investment; it is fully guaranteed.

Range: 1 - 10

98. DK

99. RF

\section{V058_GROUNDFLOOR}

FINANCIAL FRAUD AWARENESS - GROUND FLOOR

The next one is -- this is an opportunity to get in on the ground floor of a company that is about to roll out a revolutionary new technology. Using the same scale of 1 to 10 (where 1 is not at all interested and 10 is extremely interested), how interested would you be in this investment?

Range: 1 - 10

98. DK

99. $\mathrm{RF}$

\section{V059_LOWEST50PCT}

FINANCIAL FRAUD AWARENESS - MOST INVESTORS MAKING 110 PCT

The last one is -- the lowest return you could possibly get on this investment is 50 percent annually, but most investors are making upwards of 110 percent a year -- (using the same scale of 1 to 10 where 1 is not at all interested and 10 is extremely interested) how interested would you be in this investment?

Range: 1 - 10

98. DK

99. $\mathrm{RF}$

\section{V060_IFPAID-TO-WIN}

HAS R PAID MONEY TO WIN AN AWARD

In the past 5 years, have you [or your husband/wife/partner] paid money to someone who told you that you had won a prize or a lottery or had been selected to receive an award such as money, a free vacation, or other product or service?
1. Yes
5. No
8. DK
9. $\mathrm{RF}$ 


\section{V061_USEDACCOUNT}

\section{IF ANYONE HAS USED R ACCOUNT W/O PERMISSION}

In the past 5 years, has someone without your permission used or attempted to use an existing account of yours, such as a credit or debit card, checking, savings, telephone, online, or insurance account?
1. Yes
5. No
8. DK
9. RF

\section{V062_INVESTFREEML}

\section{IF R-S HAS INVESTED AFTER FREE MEAL PRESENTATION}

In the past 5 years, did you [or your husband/wife/partner] invest money after a meeting that offered a free meal and educational information for some sort of investment, including but not limited to, a vacation timeshare or an annuity product?
1. Yes
5. No
8. DK
9. $\mathrm{RF}$

\section{V063_INVPHONECALL}

\section{IF R-S HAS INVESTED FROM PHONE CALL FROM UNKNOWN PERSON}

In the past 5 years, have you [or your husband/wife/partner] invested money in an opportunity that was introduced to you by a phone call or by an email from someone you didn't know?
1. Yes
5. No
8. DK
9. $\mathrm{RF}$

\section{V064_PENNY-OILGAS}

\section{IF R-S HAS INVESTED IN PENNY STOCKS OR OIL - GAS EXPLORATION}

In the past 5 years, have you [or your husband/wife/partner] invested money in penny stocks or in investments that guaranteed daily returns of more than $10 \%$, or participated in an investment that involved oil and gas exploration?

$\begin{array}{ll}\text { 1. } & \text { Yes } \\ \text { 5. } & \text { No } \\ \text { 8. } & \text { DK } \\ \text { 9. } & \text { RF }\end{array}$

\section{V065_IFMISLEAD}

\section{IF R-S HAS EVER PUT MONEY INTO FRAUDULENT INVESTMENT}

Investors gain and lose money all the time in financial markets for a variety of legitimate reasons. However, this question is about investment fraud, where someone knowingly misleads an investor using false information. Do you think you [or your husband/wife/partner] have ever put your money into a fraudulent investment?
1. Yes
5. No - GO TO V067
8. DK - GO TO V067
9. RF - GO TO V067

\section{V066_IFMISLED5YRS}

IF FRAUDULENT INVESTMENT IN LAST 5 YEARS

Was that investment made in the last five years? 
1. Yes

5. No

8. DK

9. $\mathrm{RF}$

\section{V067_MISLED-RELATV}

IF RECOMMENDATION BY RELATIVE WAS FRAUDULENT

In the past five years, have you [or your husband/wife/partner] invested money in an opportunity recommended by a friend, a relative, or a financial advisor which turned out to be fraudulent?
1. Yes
5. No
8. DK
9. RF 


\section{Online Appendix B: Robustness Analysis}

Several other analyses were also examined for sensitivity analysis, in results not detailed here. First, we measured the mismatch between respondents' subjective and objective financial knowledge, as this has been proposed as a possible determinant of victimization (Gamble et al., 2015). To do so, we created a measure of financial overconfidence by subtracting each person’s standardized financial literacy score from his standardized self-rated financial knowledge score. Those with values above zero were coded as being overconfident. Nevertheless, holding constant our other controls, we found no significant impact of overconfidence on any victimization outcomes.

Second, we separately analyzed whether people responding “don’t know” to the financial literacy questions were more likely to be victims of financial exploitation. We found that this attribute had no significant impact when other controls were included.

Third, we re-estimated Table 3 using Firth Logit, a technique sometimes deployed when the observed event is relatively rare. Signs and significance levels were generally similar as those appearing in Table 3. As that approach is not amenable to the use of sample weights, our preferred results are those in Table 3 using Probit and weighted data.

\section{Online Appendix References}

Firth, D. (1993). Bias reduction of maximum likelihood estimates. Biometrika, 80(1), 27-38.

Gamble, K., Boyle, P., Yu, L., \& Bennett, D. (2015). Aging and financial decision making. Management Science, 61(11), 2603-2610

Heinze, G. (2006). A comparative investigation of methods for logistic regression with separated or nearly separated data. Statistics in Medicine, 25(24), 4216-4226.

Heinze, G. \& Schemper, M. (2002). A solution to the problem of separation in logistic regression. Statistics in Medicine, 21(16), 2409-2419. 